\title{
Model Studies on the Effectiveness of MBBR Reactors for the Restoration of Small Water Reservoirs
}

\author{
Agata Nowak ${ }^{1}$, Robert Mazur ${ }^{2,}$, Ewa Panek ${ }^{1}$, Joanna Chmist ${ }^{3}$ \\ ${ }^{1}$ Department of Geoinformation, Photogrammetry and Remote Sensing of Environment, AGH University \\ of Science and Technology in Krakow, Poland \\ ${ }^{2}$ Department of Environmental Management and Protection, AGH University of Science and Technology, \\ Poland \\ ${ }^{3}$ Department of Ecology and Environmental Protection, Poznań University of Life Sciences, Poland
}

\begin{abstract}
The authors present the Moving Bed Biofilm Reactor (MBBR) model with a quasi-continuous flow for small water reservoir restoration, characterized by high concentrations of organic pollutants. To determine the efficiency of wastewater treatment the laboratory analysis of physic-chemical parameters were conducted for the model on a semi-technical scale of 1:3. Wastewater treatment process was carried out in $24 \mathrm{~h}$ for $1 \mathrm{~m} 3$ for raw sewage. The startup period was 2 weeks for all biofilters (biological beds). Approximately $50 \%$ reduction in $\mathrm{COD}$ and $\mathrm{BOD}_{5}$ was obtained on average for the studied bioreactors. Significant improvements were achieved in theclarity of the treated wastewater, with the reduction of suspension by $60 \%$. The oxygen profile has improved significantly in 7 to 9 hours of the process, and a diametric reduction in the oxidative reduction potential was recorded. A preliminary model of biological treatment effectiveness was determined based on the conducted studies. In final stages, the operation mode was set in real conditions of polluted water reservoirs.
\end{abstract}

\section{Introduction}

The primary goal of Water Frame Directive is to achieve a good state of uniform bodies of surface water. Many large and small water reservoirs, heavily transformed by humans still require urgent corrective action in order to achieve the main aim of WFD. The process of water quality monitoring is crucial to prepare the proper environmental risk assessment (ERA). Environmental risk assessment procedures are currently being promoted by the EU as a necessary tool for further environmental risk management actions. The US EPA published Guidelines for Ecological Risk Assessment [1], nevertheless, this document contained very general guidelines for the ERA process [2]. In the EU has developed a number of specific algorithms of ERA for the surface water, and one of the most commonly applied methods is a TRIAD, developed in the UK[2]. The results of the ERA are adatabase to take further action under the environmental risk management procedure (ERM). The ERM algorithms require the

${ }^{*}$ Corresponding author: mazur@agh.edu.pl 
involvement of legal, political, economic and engineering instruments. Often these procedures are cyclical, with a constant modification of the main objectives and with control of stages andend effects. The ERA results are also a database for selecting appropriate methods for restoration of degraded water reservoirs, already at the planning stage of the ERM procedure. In order to choose thebest types of lake reclamation methods can be used multi-criteria analysis such as AHP, Rembrandt or Promethe[3, 4]. The cost of water treatment of polluted water bodies is very high, especially when they are characterized by high loads of organic pollution.

The scientific progress in Environmental Engineering provides us with informationabout new effective biotechnologies of water treatment and purification from different types of pollution. The best prospects give us interdisciplinary research in this field of environmental biotechnologies [5]. Researchers in their studyhave been looking for effective strains and consortiums of microorganisms which are able to maintain an effective biodegradation and biotransformation of different types of pollution[6, 7, 8, 9, 10, 11]. The above-mentionedstudy directions aimto develop dedicated biopreparations and high-efficiency wastewater treatment technologies [6]. Most of wastewater treatment technologies require the maintenance of controlled and homogeneous bioreactors operating conditions [12]. However, for two decades, the market of WWTP observed thedynamic development of MBBR technology, in which the main objective is to minimize power consumption and volume of the reactor while increasing the degree of wastewater treatment. This types of reactors are used in wastewater treatment from communal and industrial sources in global scale [13]. The MBBR reactors are characterizedby wide tolerance for changes in physicochemical factors (temp., $\mathrm{pH}$, redox, conductivity, organic loads, etc.) [14]. In the two decades, over 450 large and nearly 110,000 smaller WWTP have been developed around the world using a high-efficiency biofilm bed. There are therefore justified scientific grounds for the possibility of adapting this technology to the reclamation of open water bodies in temperate climate zone [13, 15]. MBBR reactors require an energy input to maintain the aeration process and flow of the medium through the bed. The application of RES (renewable energy sources) in power supply of field installation allows for energy self-sufficiency of this type of technology.

It is also possible to use traditional sources of electricity and prepare the installation in astationary mode with the blower station located on the reservoir bank [16].

\section{Methodology}

The authors conducted a study on the biological treatment efficiency of municipal wastewater in MBBR model reactors designed in laboratory scale 1:3. Four MBBR reactors were constructed with cylindrical geometryand dimensions: diameter $q=400 \mathrm{~mm}, \mathrm{~L}_{\text {tot }}=90 \mathrm{~cm}$, $\mathrm{h}_{\text {basket }}=70 \mathrm{~cm}, \mathrm{~V}_{\text {act. }}=0,088 \mathrm{~m}^{3}, \mathrm{~V}_{\text {tot. }}=0,133 \mathrm{~m}^{3}$ (Fig. 1.). The bed mediaofreactor were $3 \mathrm{~cm}$ long carriers made of an electrical conduit (PE) and thetotal active area was $30,8 \mathrm{~m}^{2}$. Each reactor was operating in plastic containers with volume $\mathrm{V}=1 \mathrm{~m}^{3}$, fully submerged, $5 \mathrm{~cm}$ below the surface of wastewater. The aeration process was carried out by fine bubble disc diffuser ( $\mathrm{p}$ $=240 \mathrm{~mm}$ ) with compressed air suppliedby rubber pipes and generated bya blower (model AT80 ). Inorder to ensure a smooth adjustment of the supplied air into reactor system, two valves were mounted: control and relief valve. A rotameters were used to measure the flow of supplied air into the bed of MBBR and Mammoth reactors.Established air flow was $Q_{p}=2,2 \mathrm{~m}^{3} \cdot \mathrm{h}^{-1}$, at which the flow and velocity of the wastewater through the reactor was obtained, respectively: $Q_{w}=8 \mathrm{~m}^{3} \cdot \mathrm{h}^{-1}$ and $\mathrm{v}=0,38 \mathrm{~m} \cdot \mathrm{s}^{-1}$. The above air flow ensured the full circulation of the carriers into the bed and the biofilm on the colliding carriers wasn't intensively detached from theexternal surface. The startup period for biological bed was 2 weeks, after which it was obtained a stable process for the wastewater treatment. The bioreactors were operated on the wastewater after primary mechanical treatment by rotary mechanical coarse in Left-side WWTP 
in Poznan. The average loads of CODwere in the range $500 \div 600 \mathrm{mg} \mathrm{O}_{2} \cdot \mathrm{dm}^{-3}$ in raw wastewater. Nutrients concentration was recorded respectively in ranges: $\mathrm{PO}_{4}^{-3} 7-14 \mathrm{mg} \cdot \mathrm{dm}^{-3}$, $\mathrm{NH}^{4+} 27 \div 84 \mathrm{mg} \cdot \mathrm{dm}^{-3}, \mathrm{NO}^{3-} 1,2 \div 2,6 \mathrm{mg} \cdot \mathrm{dm}^{-3}, \mathrm{NO}^{2-} 0,08 \div 1,4 \mathrm{mg} \cdot \mathrm{dm}^{-3}$ in raw sewage.

The hydraulic retention time was:

$$
\mathrm{RT}=\frac{\mathrm{V}_{\mathrm{act}}}{\mathrm{Q}_{\mathrm{D}}}[\mathrm{d}]=\frac{0.088 \mathrm{~m}^{3}}{1 \frac{\mathrm{m}^{3}}{\mathrm{~d}}}=0,088[\mathrm{~d}]
$$

where: $\mathrm{V}_{\text {act }}$-volume of thereactor, $\mathrm{Q}_{\mathrm{d}}$ - influent flow rate

The operation mode was divided into 1,5 h of aeration (nitrification phase) and 1,5 h without aeration (denitrification phase). The floating carriers provide adequate biomass suspension of biofilm in the denitrification phase, no additional mixing is required. The samples of treatedwastewater were taken after treatment process, before its discharging from model reactor chambers.

Table 1 presents laboratory technics used during analysis of physical and chemical parameters of studied wastewater (raw and after treatment).

Table 1. Laboratory procedures and methods of studied physical and chemical parameters.

\begin{tabular}{|c|c|c|}
\hline No. & Method & Used procedures \\
\hline 1 & $\mathrm{COD}$ & $\begin{array}{r}\text { Procedure Merckmillipore in NOVA 60 Spectroquant } \AA \text {, } 114555 \text { - CODcuvette } \\
\text { test, method for range: } 100-1000 \mathrm{mg} \mathrm{O}_{2} \cdot \mathrm{dm}^{-3}\end{array}$ \\
\hline 2 & $\mathrm{BOD}_{5}$ & $\begin{array}{r}\text { According to the procedure Oxi-top (WTW company) in } 5 \text { days period (in dark } \\
\left.\text { glass bottles with continuous stirring and temperature } 20^{\circ} \mathrm{C}\right) .\end{array}$ \\
\hline 3 & $\mathrm{NH}^{4+}$ & $\begin{array}{r}\text { Spectrophotometric method, by spectrophotometer Spectroquant NOVA } 60 \text { by } \\
\text { Merck. Method PB-06, issue 2 from 1 0.05.2007. }\end{array}$ \\
\hline 5 & $\mathrm{NO}^{3-}$ & $\begin{array}{r}\text { Spectrophotometric method, by spectrophotometer Spectroquant NOVA } 60 \text { by } \\
\text { Merck. Method PB-04 issue 2 from 10.05.2007. }\end{array}$ \\
\hline 6 & $\mathrm{NO}^{2-}$ & $\begin{array}{r}\text { Spectrophotometric method, by spectrophotometer Spectroquant NOVA } 60 \text { by } \\
\text { Merck. Method PB-05 issue 2 from 10.05.2007. }\end{array}$ \\
\hline 7 & $\mathrm{PO}_{4}^{3-}$ & $\begin{array}{r}\text { Spectrophotometric method, by spectrophotometer Spectroquant NOVA } 60 \text { by } \\
\text { Merck. Method PB-07 issue 2 from 10.05.2007. }\end{array}$ \\
\hline
\end{tabular}




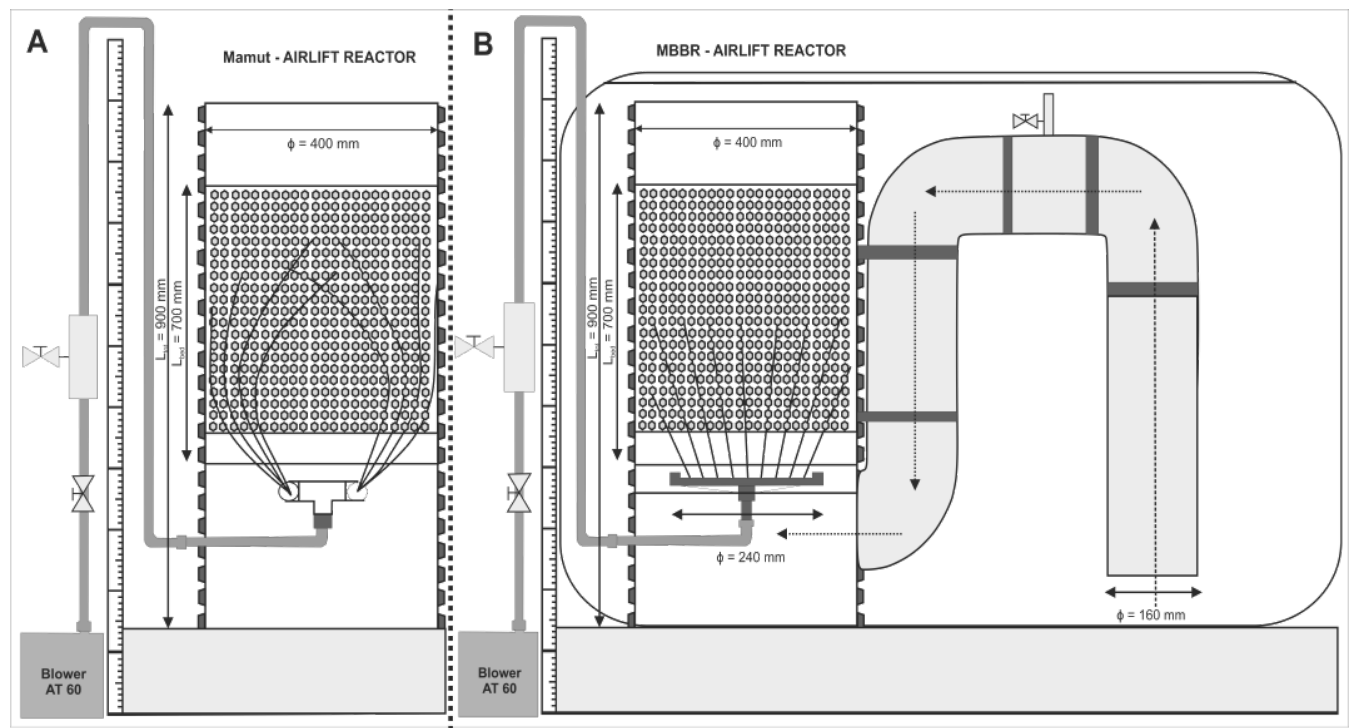

Fig. 1. Experimental MBBR reactors: A. MBBR - type Mammoth airliftreactor and B.classical MBBR airliftreactor in scale 1:3 in Left-side WWTP in Poznan. 


\section{Results}

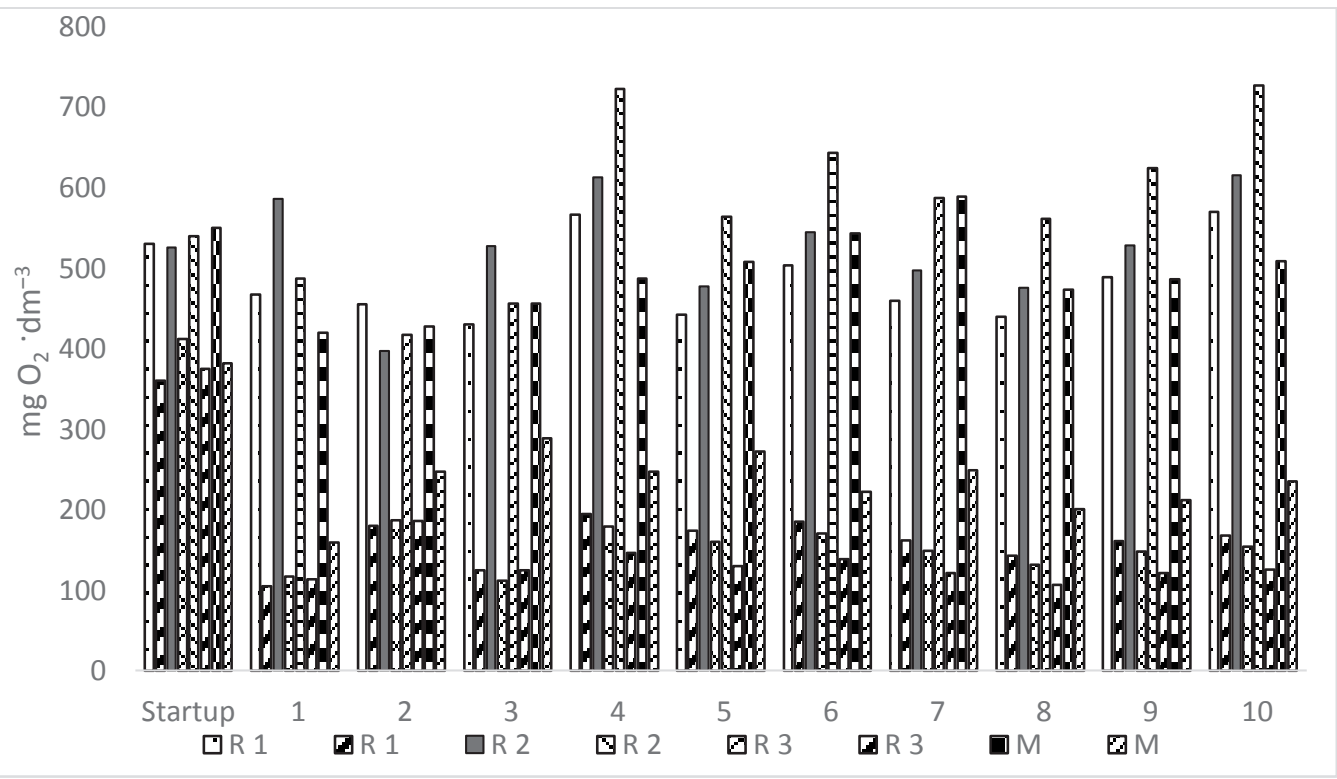

Fig. 2. Reduction of COD after $24 \mathrm{~h}$ wastewater treatment $\left[\mathrm{mg} \mathrm{O}_{2} \cdot \mathrm{dm}^{-3}\right]$.

Figure 2 and 3 present changes in $\mathrm{COD}$ and $\mathrm{BOD}_{5}$ after $24 \mathrm{~h}$ of wastewater treatment process in bioreactors $\mathrm{MBBR}(\mathrm{R} 1, \mathrm{R} 2, \mathrm{R} 3)$ and Mammoth $(\mathrm{M})$. The startup period is characterized by worst treatment results in comparison to further experiments after 2 weeks later, in which the efficiency of the treatment has improved significantly. The article presents results for 10 randomly chosen treatment processes in two months period of theexperiment.

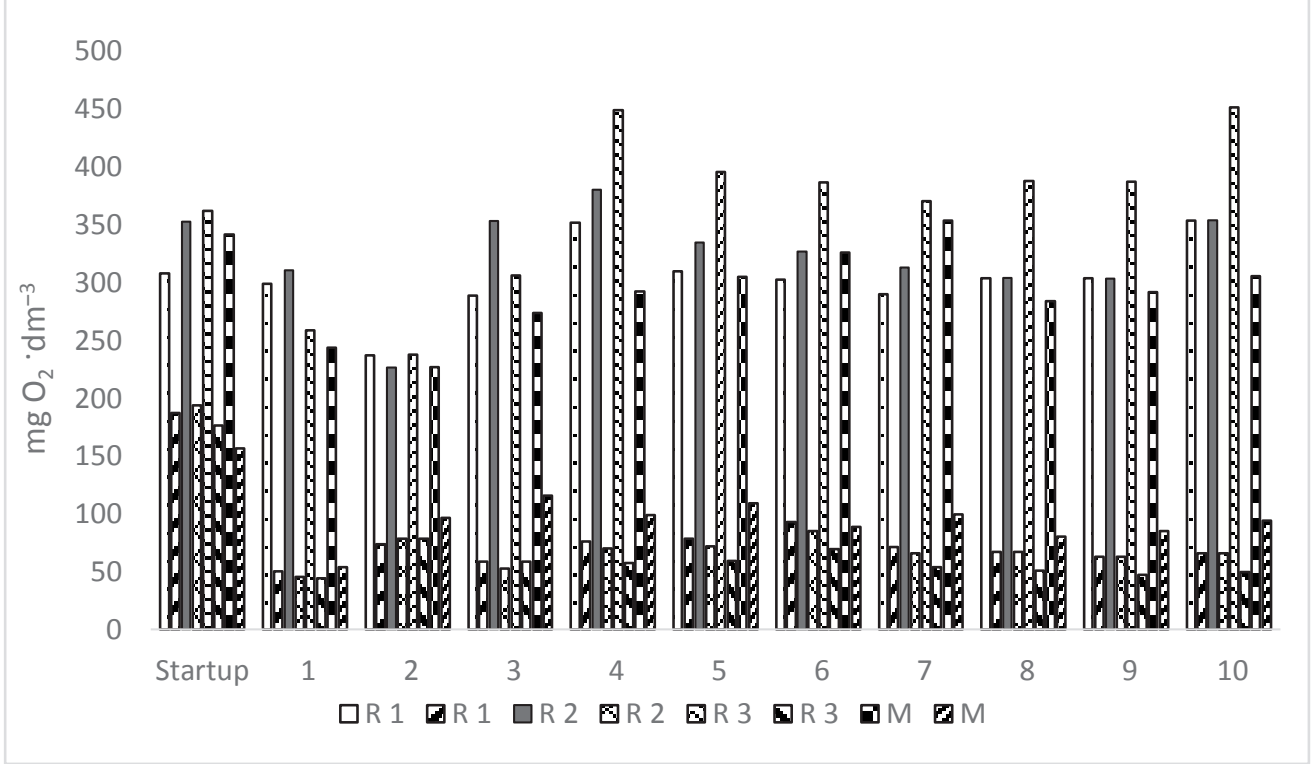

Fig. 3. Reduction of $\mathrm{BOD}_{5}$ after $24 \mathrm{~h}$ wastewater treatment process $\left[\mathrm{mg} \mathrm{O}_{2} \cdot \mathrm{dm}^{-3}\right]$. 


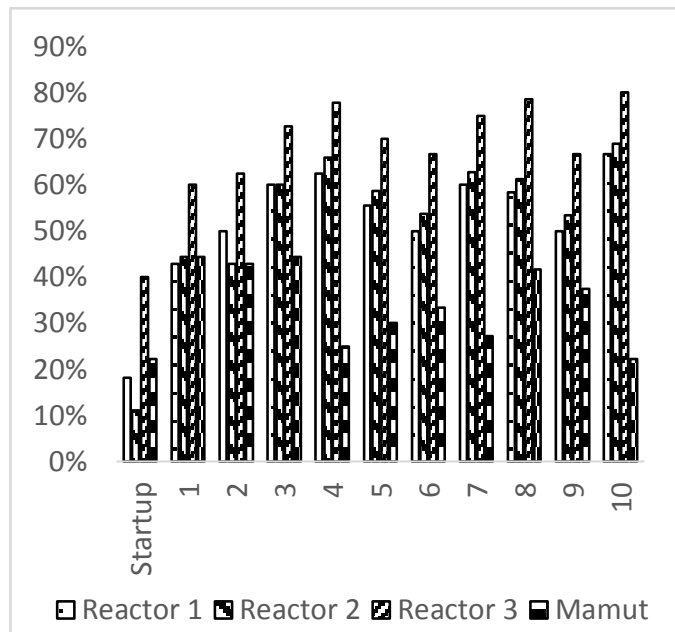

A.

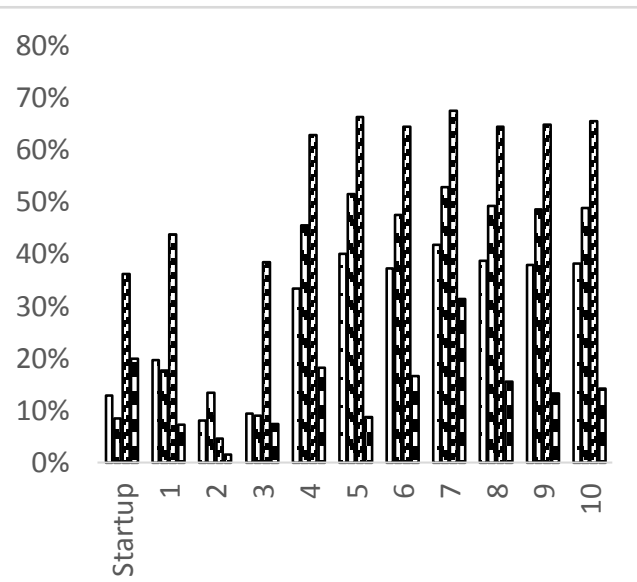

口Reactor 1 Reactor 2 Reactor 3 घMamut

B.

Fig. 4. Reduction of nutrients after $24 \mathrm{~h}$ MBBR operation: $\mathrm{A} . \mathrm{PO}_{4}{ }^{3-}$ and $\mathrm{B} . \mathrm{NH}_{4}{ }^{+}[$in \%].

The changes in nutrients concentration $\mathrm{PO}_{4}{ }^{3-}, \mathrm{NH}_{4}{ }^{+}$and $\mathrm{NO}_{3}{ }^{-}$(Fig. 4 and 5) were statistically significant due to the initial level with exception of changes in $\mathrm{NO}_{2}^{-}$ions levels. The concentration of this ions was highly variable depending on whether aerobic or anaerobic conditions were provided. Due to the accepted sampling procedure during the aeration phase, the $\mathrm{NO}_{2}^{-}$concentrations in the experimental samples were characterized by significant nonspecific changes.

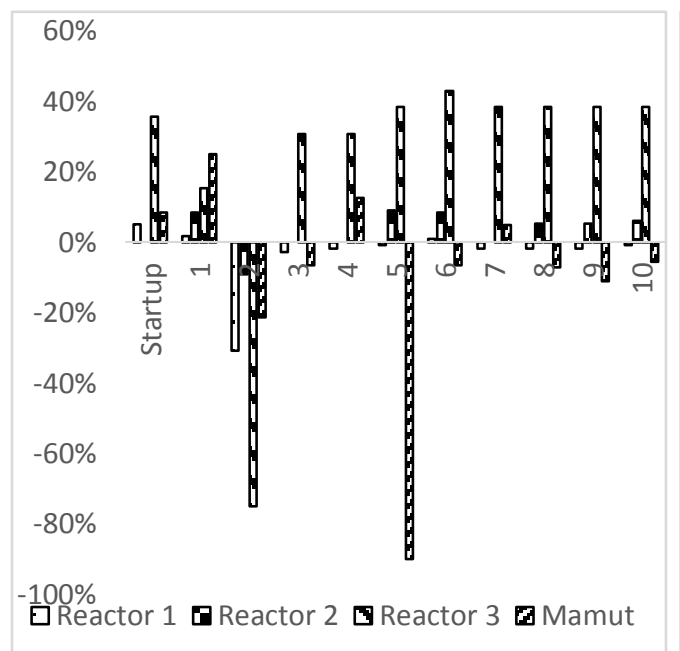

A.

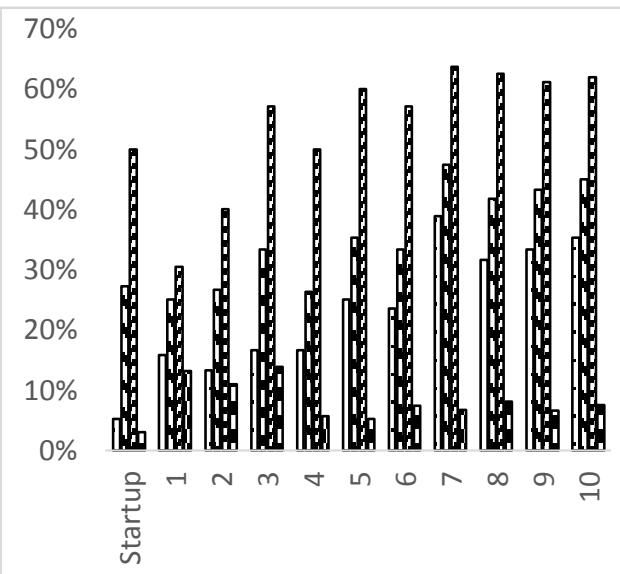

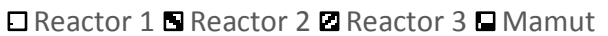

B..

Fig. 5. Reduction of nutrientsafter $24 \mathrm{~h} \mathrm{MBBR}$ operation: $\mathrm{A} . \mathrm{NO}_{2}^{-}$and $\mathrm{B} . \mathrm{NO}_{3}{ }^{-}$[in \%]. 

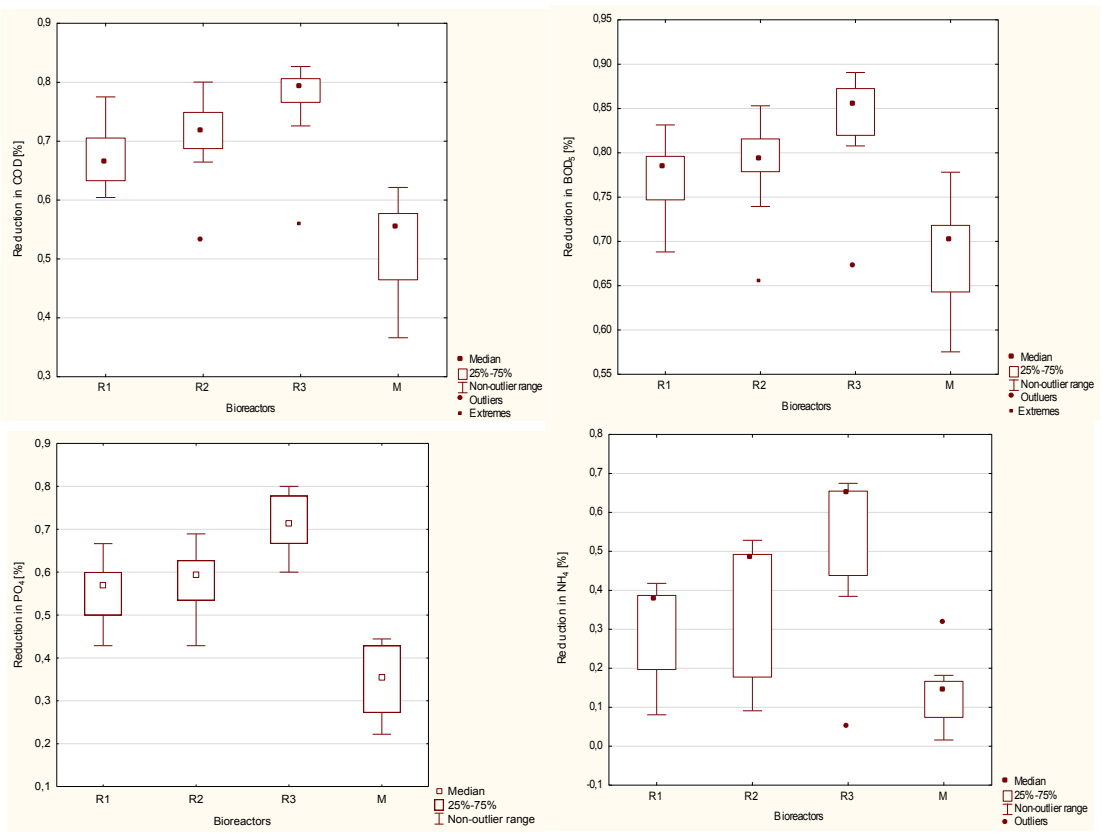

Fig 6. Statistical analysis of theeffectiveness of reduction of selected pollutants in investigated reactors.

\section{Discussion}

The experiment was conducted during the summer months since 1st of July till 10th of September, thedaily temperature of treated wastewater were ranged in $20-28^{\circ} \mathrm{C}$ and were conducive to biochemical processes. The concentration of oxygen in raw sewage in the bed dropped to level $0,5 \mathrm{mg} \cdot \mathrm{dm}^{-3}$ and during treatment process were raised to level about $8 \mathrm{mg}$. $\mathrm{dm}^{-3}$ into classical MBBR (with fine bubble aeration) inversely proportional to the concentration of COD and to level about $6 \mathrm{mg} \cdot \mathrm{dm}^{-3}$ into Mammoth bioreactor. The reduction of COD values in MBBR reactors ranged from 52 to $82 \%$, and significantly worse results obtained from the reactor type Mammoth 36 - 62\%, (figure 2) which was reflected in changes in the dynamics of the oxygen profiles for both types of reactors during theprocess. The changes in thelevel of easily biodegradable organic compounds expressed as $\mathrm{BOD}_{5}$ presented much better in MBBR reactors in the range $65-89 \%$ and for theMammoth reactor in therange $57-78 \%$ of total reduction (Fig. 3). Statistical analysis confirmed the statistically significant differences between results for the MBBR and Mammoth reactors, with exception of changes in theconcentration of $\mathrm{NO}_{2}^{-}$ions. Many authors have confirmed the effectiveness of the reduction of organic pollutants in MBBR reactors $[14,17,18]$ there are no articles devoted to acomparison of the type of aeration in the wastewater treatment efficiency for MBBR reactors, which differ in the types of aerators. The nutrients level analyses also showed statistically significant differences in changesof their concentrations $\mathrm{PO}_{4}{ }^{3-}(11-80 \%)$ (Fig. 4a, 6) and $\mathrm{NH}_{4}{ }^{+}(4-67 \%)$ (Fig. 4a, 6) in relation to baseline levels. The results of $\mathrm{NO}^{3-}$ and $\mathrm{NO}^{2-}$ ions concentrations due to reactor operation mode were characterized by significant variability depending on the kinetics of process and the nitrification stage (Fig. 5) [19, 20, 21].The comparison of the wastewater treatment efficiency between two types of MBBR reactors (Fig. 1) also showed significantly better results for reactors equipped with disk diffusor.The final results clearly show that disk diffusers are better in the wastewater treatment process than air-lift reactor in Mammoth mode. 
Based on the obtained results and literature reports [19] can be demonstrated that tested MBBR reactors are the appropriate solution for the reclamation of water reservoirs heavily polluted by organic compounds and with high nutrients concentration. The similar solutions are used in wastewater treatment of highly productive fish farms[22]. The conception project of floating reclamation platforms with MBBR reactors are still ongoing, with theapplication of new RES technologies, which allow them for the independent operation on the lakes. Despite the wastewater treatment process in laboratory bioreactors were conducted in quasi-flow mode, nevertheless, the obtained efficiencies allow us to conclude that the tested technologies are promising for the application in the reclamation of small water reservoirs [23]. Hydraulic and biotechnological studies allowed better estimation of the number of reactors necessary in the restoration of polluted water reservoirs, with respect to its volume. The proposed method of reclamation with MBBR reactors can be compared to the in-situ WWTP (wastewater treatment plant) technology. The high stability of the wastewater treatment process makes these types of reactors particularly valuable in temperate climate zones [24].

\section{Conclusions}

Tested laboratory models of MBBR reactors characterized by high efficiency of wastewater treatment, which proves their usefulness for the purposes of the degraded water reservoirs restoration.

Further studies are needed to determine their effectiveness of sewage treatment with low loads of organic pollutants.

Investigated bioreactors were designed on the semi-technical scale, which allows for extrapolation of laboratory results to field conditions, with no significant statistical error.

MBBR belongs to unique technologies, which can be easily adapted to the treatment processes of small water reservoirs.

\section{References}

1. EPA. Assessment, E. R. Guidelines for Ecological Risk Assessment.(1998)

2. G. W. Suter II, Ecological risk assessment. CRC press.(2016).

3. A.Hadipour, T.Rajaee, V.Hadipour\&S.Seidirad, Multi-criteria decision-making model for wastewater reuse application: a case study from Iran. Desalination and Water Treatment, 57(30), 13857-13864.(2016).

4. E.Wąsik, K.Chmielowski\&A. Operacz, PCA jako narzędzie eksploracji danych charakteryzujących pracę komór nitryfikacji oczyszczalni ścieków W Trepczy. ActaScientiarumPolonorumFormatioCircumiectus, 16(1), 209-222. (2017).

5. E. Wąsik, P. Bugajski, K. Chmielowski, A. Nowak \&R. Mazur. Crystallization of struvite and hydroxyapatite during removal of biogenic compounds on the filter bed. PrzemysłChemiczny, 96/8, 1739-1743.(2017).

6. P. Kaszycki, P. Petryszak\&H. Kołaczek. "Biological treatment of wastewaters generated by furniture industry part 2. Construction of a specialized activated sludge and optimization of bioprocess parameters in semi-technical scale tests." Ecological Chemistry and Engineering. A 15.11 1257-1271.(2008)

7. G. T.Ooi, M. E.Casas, H. R.Andersen\&K. Bester. Transformation products of clindamycin in moving bed biofilm reactor (MBBR). Water Research, 113, 139-148.(2017). 
8. E.Wąsik\&K. Chmielowski, Ammonia and indicator bacteria removal from domestic sewage in a vertical flow filter filled with plastic material. Ecological Engineering, Volume 106, Part A, Pages 378-384. (2017).

9. P. Bugajski, K. Chmielowski\&G. Kaczor,Optimizing the Percentage of Sewage from Septic Tanks for Stable Operation of a Wastewater Treatment Plant. Polish Journal of Environmental Studies, 25(4), 1421-1425. (2016).

10. R. Mazur, D. Bedla, K. Chmielowski, A. Nowak\&J. Mazurkiewicz, Wpływ warunków tlenowych na skuteczność oczyszczania ścieków bytowych w technologii zatapialnych filtrów włókninowych. Przemysł Chemiczny, 96(8), 1513-1517. (2016).

11. K. Chmielowski\&R. Ślizowski, Effect of grain-size distribution of sand on the filtrate quality in vertical-flow filters. PrzemysłChemiczny, 87(5), 432-434. (2008).

12. P.Bugajski, K.Chmielowski\&G. Kaczor,Wpływ wielkości dopływu wód opadowych na skład ścieków surowych w małym systemie kanalizacyjnym. Acta ScientiarumPolonorumFormatioCircumiectus, 15(2), 3-11.(2016).

13. T. Leiknes\&H. Ødegaard, The development of a biofilm membrane bioreactor. Desalination, 202(1), 135-143.(2007).

14. H.Ødegaard, B.Rusten\&F. Wessman, State of the art in Europe of the moving bed biofilm reactor (MBBR) process. In Proceedings of the 77th Annual Water Environment Federation Technical Exposition and Conference, New Orleans, Louisiana, (2-6).(2004).

15. K.Chmielowski\&R. Ślizowski, Defining the optimal range of a filter bed's d(10) replacement diameter in vertical flow sand filters. Environment Protection Engineering, 34(3), 35-42.(2008).

16. R.Kollmann, G. Neugebauer, F.Kretschmer, B.Truger, H.Kindermann, G.Stoeglehner\&M. Narodoslawsky, Renewable energy from wastewater-Practical aspects of integrating a wastewater treatment plant into local energy supply concepts. Journal of Cleaner Production, 155, 119-129.(2017).

17. G. Andreottola, P. Foladori, M. Ragazzi\&F. Tatano,Experimental comparison between MBBR and activated sludge system for the treatment of municipal wastewater. Water Science \& Technology, 41(4), 375-382.(2000).

18. K. Miksch\&J. Sikora, Biotechnologia ścieków” Wydawnictwo Naukowe PWN(2010).

19. R.Delatolla, B.Young \&A. Stintzi, Application of the MBBR Technology to Achieve Nitrification Below $1^{\circ} \mathrm{C}$ : Biofilm and Microbiome Analysis. In Frontiers International Conference on Wastewater Treatment and Modelling (pp. 513-517). Springer, Cham.(2017).

20. T.Abzazou, R., M.Araujo, M. Auset\&H. Salvadó, Tracking and quantification of nitrifying bacteria in biofilm and mixed liquor of a partial nitrification MBBR pilot plant using fluorescence in situ hybridization. Science of the Total Environment, 541, 11151123.(2016).

21. B.Young, R.Delatolla, K.Kennedy, E.Laflamme\&A. Stintzi, Low temperature MBBR nitrification: Microbiome analysis. Water Research.(2017).

22. A.Kamstra, E. Blom\&B. F. Terjesen, Mixing and scale affect moving bed biofilm reactor (MBBR) performance. Aquacultural Engineering.(2017).

23. D. Młyński, K. Chmielowski \& A. Młyńska. The analysis of the quantity variability of the sewage inflowing to the selected wastewater treatment plants of Sanok district ActaSci.Pol. Form. Cir. 16.1: 77-89. (2017) 
24. B.Rusten, B.Eikebrokk, Y.Ulgenes\&E. Lygren, Design and operations of the Kaldnes moving bed biofilm reactors. Aquaculturalengineering, 34(3), 322-331.(2006). 